\title{
Preference ve spotřebě potravin bohatých na bílkoviny
}

\author{
Michal Novák
}

Vedoucí práce: RNDr. Jitka Bartošová, Ph.D.

\section{1. Úvod}

\subsection{Ordinalistická teorie užitku}

Teorie spotřebitelského výběru může být vyjádřena pomocí spotřebitelských preferencí a užitek je posuzován jako způsob popisu preferencí. Spotřebitel si vybírá ze spotřebního koše dle preferencí tak, aby maximalizoval svůj užitek.

Základní deskripcí pro analýzu výběru jsou preference spotřebitele a užitek je způsob jejich popisu. Spotřební koš je popis situace spotřebitele, tj. vektor $\vec{x}=\left(x_{1}, x_{2}, \ldots, x_{n}\right)$, jehož složky představují množství spotřebovávaných statků. Užitková funkce je způsob pro přidělení určitého čísla (pořadí) každému spotřebnímu koši tak, aby preferovanější spotřební koš měl číslo vyšší než méně preferovaný spotřební koš. Preference uspořádává spotřební množinu dle užitku, který spotřeba jednotlivých komodit přináší. Toto uspořádání může být ostré (výrazná preference) nebo neostré (mírná preference).

Relace neostrá preference $\widetilde{\widetilde{\zeta}}$ definuje neostré uspořádání na spotřební množině. Koš $\left(x_{1}, x_{2}\right)$ je preferován před košem $\left(y_{1}, y_{2}\right)$ pokud užitek $\left(x_{1}, x_{2}\right)$ je vyšší než $\left(y_{1}, y_{2}\right)$. To lze symbolicky vyjádřit jako $\left(x_{1}, x_{2}\right) \succ\left(y_{1}, y_{2}\right)$ pouze pokud $u\left(x_{1}, x_{2}\right)>u\left(y_{1}, y_{2}\right)$.

Základním předpokladem, který umožňuje spotřebiteli racionální volbu, je splnění tři základních vlastností (axiomů):

1) úplnost srovnání

$$
\vec{x}_{1} \underset{\succ}{\widetilde{\tau}} \vec{x}_{2} \vee x_{2} \underset{\succ}{\approx} x_{1}
$$

ř́ká, že každé dvě situace $\vec{x}_{1}$ a $\vec{x}_{2}$ jsou srovnatelné, tzn. je známo, kterou z těchto situací bude spotřebitel preferovat,

2) reflexivnost

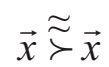

znamená, že jakákoliv situace spotřebitele je srovnatelná, každý spotřební koš musí být alespoň tak dobrý, jako ten stejný spotřební koš,

3) tranzitivnost

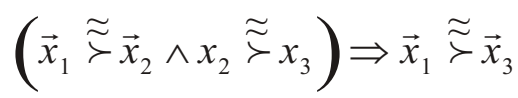

1 BARTOŠOVÁ, Jitka. Modelování v ekonomii : Podpưrný učební text k on-line kurzu 6MI420. 1. vyd. [s.1.] : Oeconomica, 2007. 35 s. ISBN 978-80-245-1162-7. 
nám ř́iká, že jestliže preferuji spotřebitelský koš A před B a zároveň spotřebitelský koš B preferuji před spotřebním košem $\mathrm{C}$, potom lze předpokládat, že preferuji spotřební koš A před spotřebním košem $\mathrm{C}$

Relace neostrá preference definuje dvě další relace na spotřební množině. Jsou to

- relace ekvivalence (indiferentnost)

o označuje dvě rovnocenné situace

$$
\vec{x}_{1} \approx \vec{x}_{2} \Leftrightarrow \vec{x}_{1} \approx \vec{\succ}_{x_{2}} \wedge \vec{x}_{2} \underset{\widetilde{\succ}}{\vec{x}_{1}},
$$

- relace ostrá preference $\succ$

$$
x_{1} \succ x_{2} \Leftrightarrow x_{1} \underset{\widetilde{\succ}}{\widetilde{r}} x_{2} \wedge x_{1} \neq x_{2} .
$$

\subsection{Kardinalistická teorie užitku, tvorba poptávkové křivky, Gossenovy zákony}

$\mathrm{V}$ teorii je užitek považován za přímo měřitelný. Velikost užitku měřen jednak cenou, kterou je spotřebitel ochoten zaplatit, a jednak množstvím zboží, kterého je ochoten se vzdát pro dosažení požadovaného statku. Mezní př́ijmy plynoucí ze spotřeby zde vyjadřují mezní užitek a mezní náklady spojené se spotřebou vyjadřují cenu.

1. Gossenův zákon říká, že mezní užitek má s růstem objemu spotřebovávaného zboží tendenci klesat. Celkový užitek, tzn.maximální částku, kterou je spotřebitel ochoten zaplatit, získáme jako součet mezních užitků, kde užitková funkce $U=f(Q)$ je funkcí spotřebovávaného množství. Platí

$$
M U=\frac{\Delta T U}{\Delta Q} .
$$

Na trhu jednoho výrobku platí, že pokud mezní užitek je větší než cena, objem spotřeby roste, tzn. spotřebitel zvyšuje své nákupy. Pokud je mezní užitek menší než cena, objem spotřeby klesá, tzn. spotřebitel své nákupy snižuje. Při rovnosti mezního užitku a ceny nastává stav optimální spotřeby, tzn. spotřebitel je v rovnováze. Můžeme tedy říci, že spotřebitel je $\mathrm{v}$ rovnováze, jestliže $\mathrm{v}$ rámci svého rozpočtového omezení a při daných cenách nemůže svůj užitek zvýšit tím, že ztrátu jednoho statku nahradí zvýšením množství statku jiného.

Na trhu se dvěma výrobky platí

$$
\begin{gathered}
\frac{M U_{x}}{P_{x}}=\frac{M U_{y}}{P_{y}}, \\
\frac{M U_{x}}{M U_{y}}=\frac{P_{x}}{P_{y}} .
\end{gathered}
$$

2. Gossenův zákon (zákon rovnosti mezních užitků) říká, že spotřebitel porovnává, jaký užitek mu přinesou peněžní prostředky vynaložené na nákup jednotlivých statků. Racionálně jednající spotřebitel zvyšuje objem nákupu určitého statku až do bodu, kdy se mezní užitek poslední peněžní jednotky vynaložené na jeho nákup vyrovná meznímu užitku poslední peněžní jednotky vynaložené na nákup všech ostatních statků.

Stoupne-li cena, spotřebitel sníží objem nakupovaného statku, klesne-li cena, spotřebitel zvýší objem nakupovaného statku. Křivka mezního užitku (měřeného v peněžních jednotkách) je shodná s křivkou poptávky. Je zřejmé, že např́klad 


$$
\frac{2 \cdot M U_{x}}{2 \cdot P_{x}}=\frac{M U_{y}}{P_{y}},
$$

kde $M U_{y}=2 M U_{x}$ a $P_{y}=2 P_{x}$, takže pro statků platí

$$
\frac{M U_{1}}{P_{1}}=\frac{M U_{2}}{P_{2}}=\ldots=\frac{M U_{n}}{P_{n}} .
$$

Bod spotřebitelského optima nastává v situaci, kdy . Křivka poptávky je totožná s klesající křivkou mezního užitku

\subsection{Indiferenční křivky při dané funkci celkového užitku spotřebního koše, vztahy mezi mezními mírami substituce a mezními užitky}

Indiferenční křivka je množina bodů vyjadřující kombinace dvou statků, které mají pro spotřebitele stejný celkový užitek. Mezní míra substituce vyjadřuje sklon této křivky.

\subsection{Funkce celkového užitku spotřebního koše, základní modely substituce statků v podmínkách různých preferencí}

Mapa indiferenčních křivek je souhrnem všech indiferenčních křivek, kde na každé indiferenční křivce je zakreslena kombinace dvou statkủ. Čím je indiferenční křivka vzdálenější od počátku, tím vyjadřuje větší hladinu celkového užitku.

\subsubsection{Jednotlivé modely volby spotřebního koše (spotřebitelské preference) ${ }^{2}$}

\section{Model s omezenou substitucí statků}

Indiferentní statky, tzn. dvojice statků, jež vůči sobě nemají žádný vztah, mají indiferenční křivky neprotínající osy. Celkový užitek zde můžeme vyjádřit pomocí Cobb-Douglasovy funkce, jejíž indiferenční křivky mají ryze konvexní charakter.

\section{Model s neomezenou substitucí statků}

Toto je model, kde jsou př́mé substituty tzn. jeden statek může být nahrazen jiným. Indiferenční křivky protínají osy.

\section{Model s omezenou substitucí nezbytného a neomezenou substitucí zbytného}

statku

Tento model je modelem nepř́mých substitutů, kdy jeden statek je považován za nezbytný, jako např. mléko, a druhý za zbytný, jako např. telefon.

\section{Model dokonalé substituce}

Jedná se o model s dokonalými substituty, tzn. uvažujeme kvantitativní rozdíl mezi jednotlivými statky, které jsou dokonale vzájemně nahraditelné.

\section{Dokonalé komplementy}

Uvažujeme spotřebu statků najednou v pevných poměrech, např. př́ípad levé a pravé boty, kde spotřebitel má zájem pouze o celé páry bot. Proto volíme užitkovou funkci jako počet párů bot. Jakákoliv monotónická transformace této užitkové funkce zachytí stejné preference.

2 Mikroekonomie otázky [online]. 2006 [cit. 2007-04-10]. Dostupný z WWW: <http://axelx1.com/CZU/Druhy\% 20rocnik/Mikroekonomie/mikro_otazky.doc>. 


\subsubsection{Rozpočtové omezení spotřebitele (budget line). Změny rozpočtových možností a jejich vliv na rovnováhu spotřebitele}

Spotřebitel se vedle preferencí rozhoduje také na základě svých finančních možností, tzn. výše důchodu . Z hlediska modelu uvažujeme nákup dvou druhů zboží, kde spotřebitel nespoří, ani se nepůjčuje.

Spotřebitel ale nemusí vyčerpat celý disponibilní důchod na nákup těchto dvou statků a tak vznikne úspora.

Z hlediska změn uvažujeme dva druhy. Jednak se může jednat o změnu důchodu spotřebitele, kde při zvýšení důchodu dojde $\mathrm{k}$ posunu rozpočtové prrímky směrem nahoru, kdežto při snížení dochází k posunu rozpočtové přímky směrem dolů. Jednak uvažujeme změnu cen statků, kde se mění sklon rozpočtové křivky.

\subsubsection{Maximalizace celkového užitku spotřebního koše a vlastnosti rovnováhy spotřebitele}

Pro nalezení velikosti poptávky lze využít klasické metody nalezení optima spotřebitele, napřr. metodu Lagrangeových multiplikátorů. Pro Cobb-Douglasovy preference a lineární rozpočtové omezení v prrípadě dvou komodit platí vztah ${ }^{3}$

$$
L\left(x_{1}, x_{2}, \lambda\right)=U\left(x_{1}, x_{2}\right)+\lambda \cdot\left(Y-P_{1} \cdot x_{1}-P_{2} \cdot x_{2}\right)=x_{1}^{c} \cdot x_{2}^{d}+\lambda \cdot\left(I-P_{1} \cdot x_{1}-P_{2} \cdot x_{2}\right) .
$$

Rovnováha spotřebitele nastává, pokud je rozpočtová linie tečnou jedné indiferenční křivky, kde optimální úroveň pro spotřebitele z hlediska cen a prŕíjmů je bodem rovnovážným. Proto se v bodě optima mezní míra substituce na indiferenční křivce rovná mezní míre substituce na rozpočtové linii a proměny mezních užitků se rovnají cenovým relacím. Platí

$$
-M M S_{1 / 2}=\frac{M U_{2}}{M U_{1}}=\frac{P_{2}}{P_{1}} .
$$

Z hlediska maximalizace užitku spotřebního koše hledáme takovou kombinaci $x_{1}$ a $x_{2}$, která dává maximální užitek. Musí platit druhý Gossenův zákon a vztah

$$
I=P_{1} \cdot x_{1}+P_{2} \cdot x_{2},
$$

při současném dodržení rozpočtového omezení.

Při maximalizaci užitku při neomezené substituci obou statků uvažujeme funkci celkového užitku

$$
U=a x_{1}+b x_{2}+x_{1} \cdot x_{2},
$$

kde se proměny mezních užitků rovnají cenovým relacím

$$
\frac{M U_{1}}{M U_{2}}=\frac{\frac{d U}{d x_{1}}}{\frac{d U}{d x_{2}}}=\frac{a+x_{2}}{b+x_{1}}=\frac{P_{1}}{P_{2}} .
$$

3 BARTOŠOVÁ, Jitka. Modelování v ekonomii : Podpưrný učební text k on-line kurzu 6MI420. 1. vyd. [s.1.] : Oeconomica, 2007. 35 s. ISBN 978-80-245-1162-7. 


\subsection{Programy využitelné pro ekonomické modelování}

- Nejpoužívanější CAS (= Computer Algebra System) ${ }^{4}$

O freeware: Axiom, CoCoA, DoCon, DCAS, Eigenmath, GAP, GiNaC, Macaulay, Mathomatic, Maxima, Meditor, Pari/GP, Sage, Singular, WIRIS, Yacas

O komerční: Derive, Fermat, Magma, Maple, MathCad, Mathematica, MuMATH, MuPAD, REDUCE

- Nejpoužívanější software pro numerickou analýzu dat

O freeware: GNU Octave, R, Scilab

O komerční: GAUSS, LabVIEW, Mathematica, MATLAB, Sysquake

- Nejpoužívanější software pro statistické výpočty

O freeware: EasyReg, gretl, PSPP, R, SOCR

O komerční: ASReml, AcaStat, Analyse-it, BioStat, Eviews, GAUSS, GenStat, JMP, Mathematica, MedCalc, Minitab, NCSS, Origin, RATS, SAS, Stata, STATISTICA, Statgraphics, StatIt, StatPlus, SPlus, SPSS, StatsDirect, Statistix, SYSTAT, UNISTAT, VisualStat, XLStat, XploRe

- Nejpoužívanější tabulkové procesory (,,spreadsheet“)

$\bigcirc$ freeware: Gnumeric, OpenOffice.org Calc

○ komerční: Microsoft Excel, Lotus 1-2-3

O online: EditGrid, Google Docs \& Spreadsheets, iRows, Simple Spreadsheet, ThinkFree Calc, wikiCalc, Xcellery, Zoho Office Suite

\section{Motivační článek}

Při hledání vhodného tématu pro zpracování seminární práce mě zaujal mě článek „Zdroje bílkovin - minikurz výživy o bílkovinách“. Autor v něm uvádí, že bílkoviny jsou součástí našeho těla a je nutné je neustále doplňovat ve formě stravy. Nachází se v potravinách, a to jak v rostlinné podobě, tak živočišné. Nejvíce se nachází ve vejcích, mase, rybách, bramborech, rýži atd. Za nejkvalitnější zdroj bílkovin, z hlediska komplexnosti př́jmu aminokyselin potřebných pro stavbu lidských bílkovin, je považován vaječný bílek. Autoři mu přisoudili biologickou hodnotu $100 \mathrm{v}$ komparaci s jinými potravinami jako zdroji bílkovin. Hodnota udává vhodnost poměru aminokyselin v potravině, potřebných pro proteosyntézu.

V současné době převažují jako zdroj bílkovin živočišné produkty (pokrývají potřebu ze $2 / 3$ ). V době před cca 20 lety byl dle autorů poměr živočišných a rostlinných zdrojů bílkovin 1:1. Přemíra živočišných zdrojů bílkovin má neblahé důsledky pro konzumenta $\mathrm{z}$ hlediska vyššího př́ijmu cholesterolu a nasycených tuků, které mohou vést až k arterioskleróze. Vegetariánský př́stup ke konzumaci potravin autoři neshledávají jako problematický, problém vidí ve veganském př́ístupu, kde nejsou zastoupeny žádné zdroje bílkovin živočišného původu jako napřr. mléko či vejce.

Tento článek mě přivedl na myšlenku zjistit, jaké jsou preference současného českého spotřebitele při nákupu několika běžných potravin bohatých na bílkoviny.

4 Comparison of computer algebra systems [online]. 2007 , 01:56, 7 April 2007 [cit. 2007-04-10]. Dostupný z WWW: <http://en.wikipedia.org/wiki/List_of_computer_algebra_systems>. 


\section{Tab. č. 1: Biologická hodnota vybraných zdrojů bílkovin}

\begin{tabular}{|l|c|}
\hline \multicolumn{1}{|c|}{ Potravina } & Biologická hodnota \\
\hline \hline Vaječný bílek & 100 \\
\hline Ryba & 70 \\
\hline Hovězí maso & 69 \\
\hline Kravské mléko & 69 \\
\hline Hnědá rýže & 57 \\
\hline Bílá rýže & 56 \\
\hline Sojové boby & 47 \\
\hline Pivovarské kvasinky & 45 \\
\hline Celozrnná pšenice & 44 \\
\hline Burské ořřšky & 43 \\
\hline Fazole & 34 \\
\hline Brambory & 34 \\
\hline
\end{tabular}

Zdroj motivačního článku je uveden v použité literatuře [5]. Původním znění je součástí Př́lohy 1.

\subsection{Charakteristika datového souboru}

Moje semestrální práce se zabývá srovnáním spotřebních košů na trhu z hlediska spotřeby bílkovin. Pro analýzu jsem vybral tři statky, jejichž užitek pro spotřebitele budu srovnávat. Jsou to mléko, drůbež a ryby. Dále chci zjistit vývoj preferencí v závislosti na rozpočtovém omezení pro vybrané potraviny.

Pro analýzu jsem použil data sebraná Českým statistickým úřadem a využiji hodnoty pro roky 2001-2005.

Na takto sebraná data použiji pro získání užitkové funkce metodu Cobb-Douglasových preferencí a metodu Lagrangeových multiplikátorů pro určení spotřebitelského optima.

Zdroje dat jsou uvedeny v použité literatuře pod čísly [7] a [8].

\subsection{Analýza}

$\mathrm{Z}$ důvodu použití počítačových programů při analýze a lepší práci s nimi, budu používat pro statek $x_{1}$ označení $x$. Pro statek $x_{2}$ označení $y$.

\subsubsection{Spotřebitelský koš [mléko, drůbež]}

$\mathrm{K}$ výpočtu položky průměr je použit geometrický průměr hodnot jednotlivých let (viz Tabulka 2). Spotřebu mléka vyjadřuji proměnnou $x$ a spotřebu drůbeže proměnnou $y$. 
Tab. č. 2: Odhad Cobb-Douglassových preferencí

\begin{tabular}{|c|r|r|r|r|r|r|r|r||}
\hline rok & cena (mléko) & $\begin{array}{c}\text { spotřeba } \\
\text { (mléko) }\end{array}$ & $\begin{array}{c}\text { cena } \\
\text { (drůbě̌) }\end{array}$ & $\begin{array}{c}\text { spotřeba } \\
\text { (drůbež) }\end{array}$ & $\begin{array}{c}\text { I (mléko }+ \\
\text { drůbež) }\end{array}$ & \multicolumn{1}{c|}{ S1 } & \multicolumn{1}{c|}{ S2 } & U(x,y) \\
\hline \hline 2001 & 13,48 & 58,9 & 60,55 & 22,9 & 2180,567 & 0,364112637 & 0,635887363 & 32,30156369 \\
\hline 2002 & 13,87 & 60,2 & 46,23 & 23,9 & 1939,871 & 0,43042759 & 0,56957241 & 35,57008012 \\
\hline 2003 & 13,38 & 56,8 & 53,60 & 23,8 & 2035,664 & 0,373334696 & 0,626665304 & 32,93154602 \\
\hline 2004 & 14,35 & 59,8 & 51,80 & 25,3 & 2168,67 & 0,395694135 & 0,604305865 & 35,55856272 \\
\hline 2005 & 14,45 & 53,8 & 51,60 & 26,1 & 2124,17 & 0,365982949 & 0,634017051 & 34,01034504 \\
\hline suma & $\mathbf{6 9 , 5 3}$ & $\mathbf{2 8 9 , 5}$ & $\mathbf{2 6 3 , 7 8}$ & $\mathbf{1 2 2}$ & $\mathbf{1 0 4 4 8 , 9 4 2}$ & $\mathbf{1 , 9 2 9 5 5 2 0 0 7}$ & $\mathbf{3 , 0 7 0 4 4 7 9 9 3}$ & $\mathbf{1 7 0 , 3 7 2 0 9 7 6}$ \\
\hline průměr & $\mathbf{1 3 , 8 9 9 1 5 6 4 4}$ & $\mathbf{5 7 , 8 5 0 7 1 3 0 5}$ & $\mathbf{5 2 , 5 5 7 7 1 2 9 2}$ & $\mathbf{2 4 , 3 7 3 2 9 6 6 2}$ & $\mathbf{2 0 8 7 , 7 8 7 1 7 3}$ & $\mathbf{0 , 3 8 5 1 3 3 1 7 9}$ & $\mathbf{0 , 6 1 3 5 7 0 5 5 1}$ & $\mathbf{3 4 , 0 4 8 2 7 7 7 6}$ \\
\hline
\end{tabular}

Odhadnutá užitková funkce má tvar

$$
U=x^{0,39} \cdot y^{0,61}
$$

a př́slušnou Lagrangeovu funkci můžeme tedy vyjádřit vztahem

$$
L(x, y, \lambda)=U+\lambda \cdot(2088-14 x-53 y) .
$$

Zobrazení indiferenčních křivek v letech 2001 - 2005, určení optima spotřebitele s využitím programů Derive a Maple

Odhadnutou užitkovou funkci využijeme k zobrazení indiferenčních křivek. Vztahy pro rozpočtové omezení a indiferenční křivky v jednotlivých letech si nejprve zapíšeme do programu:

$$
\begin{aligned}
& \text { \#12: } 2088=14 \cdot x+53 \cdot y \\
& \text { \#13: } x^{0.36} \cdot y^{0.64}=32.3 \\
& \text { \#14: } x^{0.43} \cdot y^{0.57}=35.57 \\
& \text { \#15: } x^{0.37} \cdot y^{0.63}=32.93 \\
& \text { \#16: } x^{0.4} \cdot y^{0.6}=35.56 \\
& \text { \#17: } x^{0.37} \cdot y^{0.63}=34
\end{aligned}
$$

Grafickým zobrazením těchto rovnic pak získáme mapu indiferenčních křivek pro jednotlivé roky a přímku znázorňující rozpočtové omezení. 
Obr. ̌̌. 1

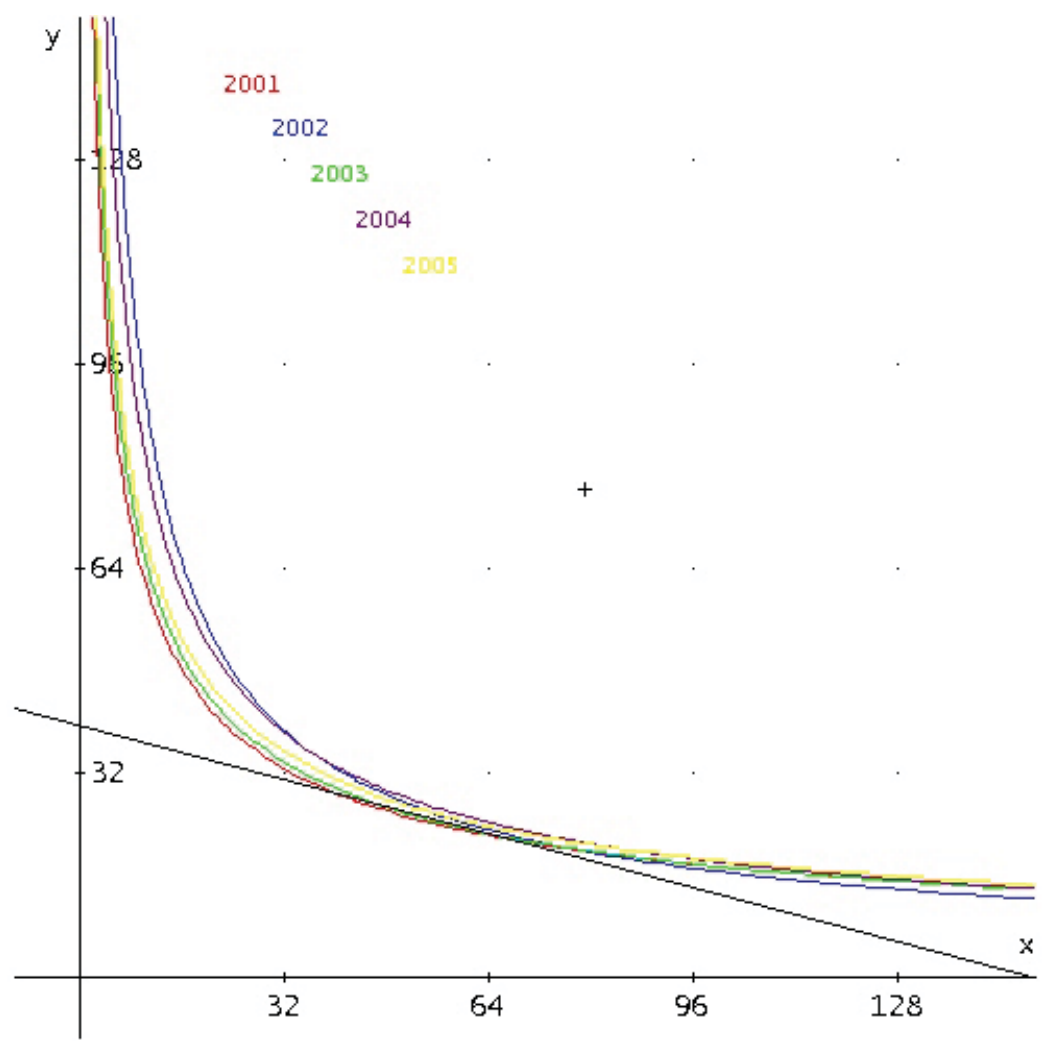

Pro určení optima spotřebitele použijeme Lagrangeovu funkci. Parciální derivace Lagrangeovy funkce podle jednotlivých proměnných položíme rovny nule a řešíme jako soustavu tří rovnic o třech neznámých.

$$
\begin{aligned}
& \text { \#1: } x^{0.39} \cdot y^{0.61} \\
& 0.39 \quad 0.61 \\
& \text { \#2: } x^{0.39} \cdot y^{0.61}+\lambda \cdot(2088-14 \cdot x-53 \cdot y) \\
& \text { \#3: } \quad \frac{d}{d x}\left(x^{0.39} \cdot y^{0.61}+\lambda \cdot(2088-14 \cdot x-53 \cdot y)\right) \\
& \# 4 \\
& \frac{39 \cdot y^{61 / 100}}{100 \cdot x^{61 / 100}}-14 \cdot \lambda \\
& \# 5: \quad \frac{d}{d y}\left(x^{0.39} \cdot y^{0.61}+\lambda \cdot(2088-14 \cdot x-53 \cdot y)\right) \\
& \text { \#6 } \\
& \frac{61 \cdot x^{39 / 100}}{100 \cdot y^{39 / 100}}-53 \cdot \lambda \\
& \# 7: \frac{d}{d \lambda}\left(x^{0.39} \cdot y^{0.61}+\lambda \cdot(2088-14 \cdot x-53 \cdot y)\right) \\
& \text { \#8 } \\
& -14 \cdot x-53 \cdot y+2088
\end{aligned}
$$


Program Derive bohužel neumožňuje řešit soustavy nelineárních rovnic, tudíž k řešení vzniklé soustavy využiji programu Maple ve verzi 10.06.

$$
\begin{aligned}
& \left.\begin{array}{c}
>\text { soustava }:=\left\{\left(\frac{39 \cdot y^{\frac{61}{100}}}{100 \cdot x^{\frac{61}{100}}}-14 \cdot \lambda\right)=0,\left(\frac{61 \cdot x^{\frac{39}{100}}}{100 \cdot y^{\frac{39}{100}}}-53 \cdot \lambda\right)=0,(-14 \cdot x-53 \cdot y+2088)=0\right. \\
\text { soustava }:=\left\{-14 x-53 y+2088=0, \frac{39}{100} \frac{y^{\frac{61}{100}}}{x^{\frac{61}{100}}}-14 \lambda=0, \frac{61}{100} \frac{x^{\frac{39}{100}}}{y^{\frac{39}{100}}}-53 \lambda=0\right.
\end{array}\right\} \\
& \text { [> solve (soustava, }\{x, y, \lambda\}) \\
& \left\{x=\frac{10179}{175}, y=\frac{31842}{1325}, \lambda=\right. \\
& \frac{1}{2516343545447273832193179208025303023800} \text { RootOf } \\
& \left(25 Z^{100}-\right. \\
& 4703390913067201656271024234524443845387924480235740279443731511176575338234898674678597 \text {, } \\
& \text { index } \left.=1)^{39} 31842^{\frac{61}{100}} 1325^{\frac{39}{100}}\right\} \\
& >\operatorname{evalf}[10](\%) \\
& \{y=24.03169811, x=58.16571429, \lambda=0.01624681299\}
\end{aligned}
$$

Při vzniklém rozpočtovém omezení 2088 Kč má optimální spotřeba mléka hodnotu 58,2 litrů na osobu ročně a optimální spotřeba drůbežího masa hodnotu $24 \mathrm{~kg}$ na osobu ročně. Toto optimum je možné vidět také na mapě indiferenčních křivek.

Odhadnutou užitkovou funkci společně s rozpočtovým omezením můžeme znázornit také pomocí 3D grafu v programu Derive.

Obr. ̌̌. 2

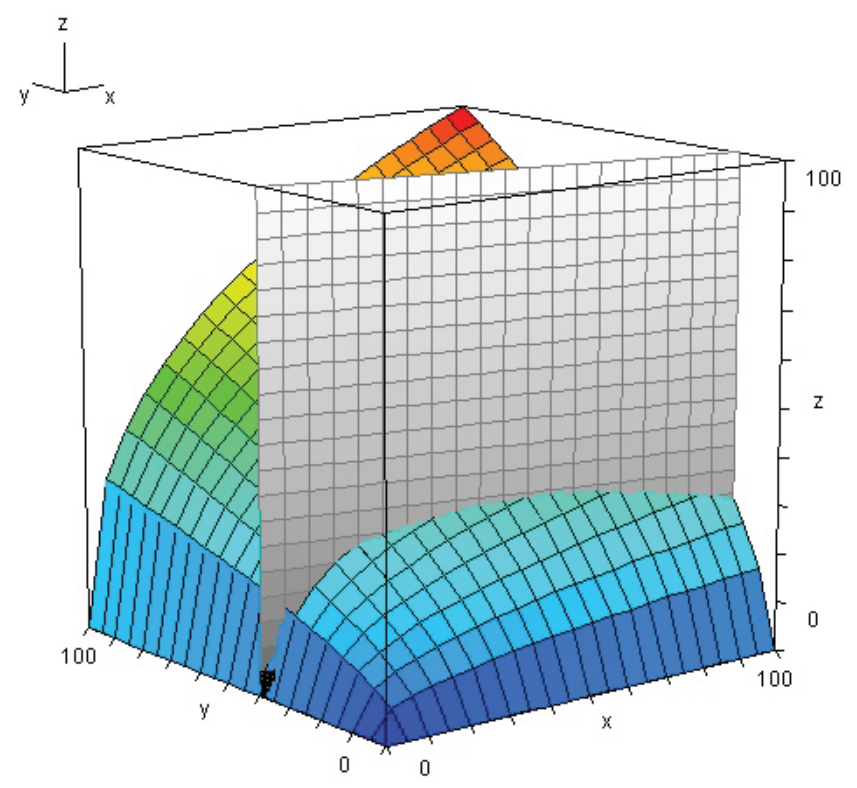

Vidíme, že 3D graf užitkové funkce je typicky kvazikonkávní a rozpočtové omezení je řezem této funkce. 


\subsubsection{Spotřebitelský koš [mléko, ryby]}

Při odhadech užitku, preferencí a spotřebitelského optima v př́ípadě spotřeby mléka a ryb budeme postupovat stejně jako v předchozím př́padě.

Tab. č. 3: Odhad Cobb-Douglassových preferencí

\begin{tabular}{||r|r|r|r|r|r|r|r|r||}
\hline rok & cena (mléko) & $\begin{array}{r}\text { spotřeba } \\
\text { (mléko) }\end{array}$ & cena (ryby) & $\begin{array}{c}\text { spotřeba } \\
\text { (ryby) }\end{array}$ & $\begin{array}{c}\text { I (mléko }+ \\
\text { ryby) }\end{array}$ & \multicolumn{1}{c|}{ S1 } & \multicolumn{1}{c|}{ S2 } & U(x,y) \\
\hline \hline 2001 & 13,48 & 58,9 & 138,06 & 5,4 & 1539,496 & 0,51573502 & 0,48426498 & 18,51753167 \\
\hline 2002 & 13,87 & 60,2 & 126,85 & 5,3 & 1507,279 & 0,553961145 & 0,446038855 & 20,36490972 \\
\hline 2003 & 13,38 & 56,8 & 114,16 & 5,3 & 1365,032 & 0,556751783 & 0,443248217 & 19,85045893 \\
\hline 2004 & 14,35 & 59,8 & 111,75 & 5,5 & 1472,755 & 0,582669894 & 0,417330106 & 22,09051956 \\
\hline 2005 & 14,45 & 53,8 & 108,53 & 5,8 & 1406,884 & 0,552575763 & 0,447424237 & 19,85932688 \\
\hline suma & $\mathbf{6 9 , 5 3}$ & $\mathbf{2 8 9 , 5}$ & $\mathbf{5 9 9 , 3 5}$ & $\mathbf{2 7 , 3}$ & $\mathbf{7 2 9 1 , 4 4 6}$ & $\mathbf{2 , 7 6 1 6 9 3 6 0 5}$ & $\mathbf{2 , 2 3 8 3 0 6 3 9 5}$ & $\mathbf{1 0 0 , 6 8 2 7 4 6 8}$ \\
\hline prüměr & $\mathbf{1 3 , 8 9 9 1 5 6 4 4}$ & $\mathbf{5 7 , 8 5 0 7 1 3 0 5}$ & $\mathbf{1 1 9 , 3 8 0 6 4 6 7}$ & $\mathbf{5 , 4 5 6 9 1 5 5 9 6}$ & $\mathbf{1 4 5 6 , 8 6 9 8 9 3}$ & $\mathbf{0 , 5 5 1 9 2 0 3 2 9}$ & $\mathbf{0 , 4 4 7 1 5 7 3 7 2}$ & $\mathbf{2 0 , 1 0 3 9 4 6 4 3}$ \\
\hline
\end{tabular}

Odhadnutá užitková funkce má v tomto případě tvar

$$
U=x^{0,55} \cdot y^{0,45}
$$

a př́islušnou Lagrangeovu funkci můžeme vyjádřit vztahem

$$
L(x, y, \lambda)=U+\lambda \cdot(1457-14 x-119 y) .
$$

Zobrazení indiferenčních křivek v letech 2001 - 2005, určení optima spotřebitele s využitím programů Derive a Maple

Odhadnutou užitkovou funkci využijeme opět k zobrazení indiferenčních křivek. Vztahy pro rozpočtové omezení a indiferenční křivky v jednotlivých letech si nejprve zapíšeme do programu:

$$
\begin{aligned}
& \text { \#1: } \quad 1457=14 \cdot x+119 \cdot y \\
& 0.52 \quad 0.48 \\
& \# 2: x^{0.52} \cdot y^{0.48}=18.52 \\
& x^{0.55} \cdot y^{0.45}=20.36 \\
& 0.56 \quad 0.46 \\
& \text { \#4: } x \text {.y }=19.85 \\
& 0.58 \quad 0.42 \\
& \text { \#5: } x \text {.y }=22.09 \\
& 0.55 \quad 0.45 \\
& \text { \#6: } x \text {. y }=19.86
\end{aligned}
$$

Grafickým zobrazením těchto rovnic získáme mapu indiferenčních křivek pro jednotlivé roky a přímku znázorňující rozpočtové omezení (viz Obrázek 3). 


\section{Obr. č. 3}

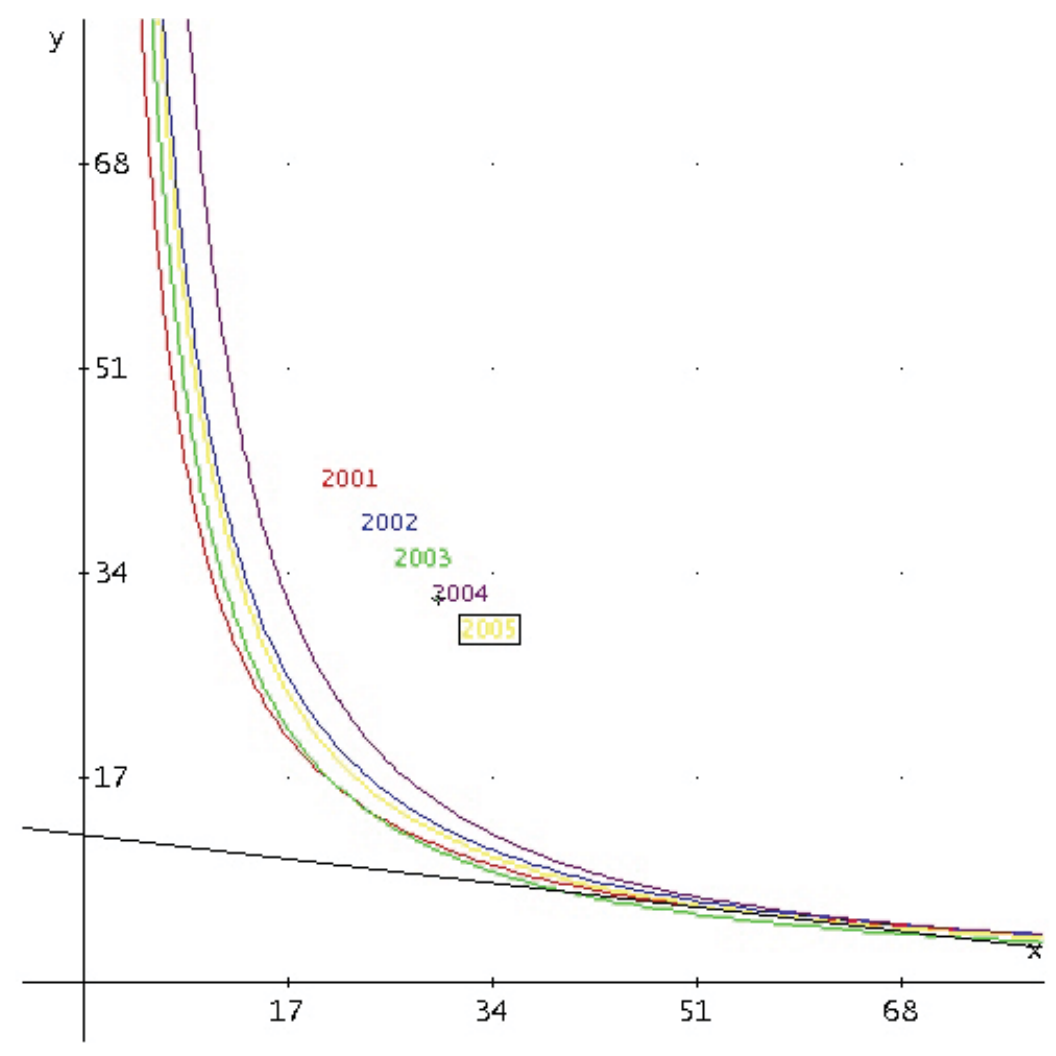

Pro určení optima použijeme Lagrangeovu funkci a určíme její parciální derivace podle jednotlivých proměnných, které položíme rovny nule.

$$
\begin{aligned}
& \# 1: \quad x^{0.55} \cdot y^{0.45}+\lambda \cdot(1457-14 \cdot x-119 \cdot y) \\
& \# 2: \quad \frac{d}{d x}\left(x^{0.55} \cdot y^{0.45}+\lambda \cdot(1457-14 \cdot x-119 \cdot y)\right) \\
& \begin{array}{c}
\frac{11 \cdot y^{9 / 20}}{20 \cdot x^{9 / 20}-14 \cdot \lambda} \\
\text { \#4: } \frac{d}{d y}\left(x^{0.55} \cdot y^{0.45}+\lambda \cdot(1457-14 \cdot x-119 \cdot y)\right)
\end{array} \\
& \text { \#5: } \quad \frac{9 \cdot x^{11 / 20}}{20 \cdot y^{11 / 20}}-119 \cdot \lambda \\
& \text { \#6: } \quad \frac{d}{d \lambda}\left(x^{0.55} \cdot y^{0.45}+\lambda \cdot(1457-14 \cdot x-119 \cdot y)\right) \\
& \text { \#7: } \quad-14 \cdot x-119 \cdot y+1457
\end{aligned}
$$

Vzniklou soustavy nelineárních rovnic vyřešíme pomocí programu Maple. 


$$
\begin{aligned}
& >\text { soustava }:=\left\{\left(\frac{11 \cdot y^{\frac{9}{20}}}{20 \cdot x^{\frac{9}{20}}}-14 \cdot \lambda\right)=0,\left(\frac{9 \cdot x^{\frac{11}{20}}}{20 \cdot y^{\frac{11}{20}}}-119 \cdot \lambda\right)=0,(-14 \cdot x-119 \cdot y+1457)=0\right\} \\
& \text { soustava }:=\left\{-14 x-119 y+1457=0, \frac{11}{20} \frac{y^{9 / 20}}{x^{9 / 20}}-14 \lambda=0, \frac{9}{20} \frac{x^{11 / 20}}{y^{11 / 20}}-119 \lambda=0\right\} \\
& >\operatorname{solve}(\text { soustava, }\{x, y, \lambda\}) \\
& \left\{\lambda=\frac{1}{70212575781185331200} 23945555887518562760916992^{11 / 20} 5^{9 / 20} 13113^{9 / 20} 2380^{11 / 20}, x=\frac{16027}{280}\right. \text {, } \\
& \left.y=\frac{13113}{2380}\right\} \\
& {[>\operatorname{evalf}[10](\%)} \\
& \{\lambda=0.01370182948, x=57.23928571, y=5.509663866\}
\end{aligned}
$$

Pro rozpočtové omezení 1457 Kč je optimum spotřeby mléka 57,2 litrů na osobu za rok a optimum spotřeby ryb $5,5 \mathrm{~kg}$ na osobu za rok. Užitková funkce je typicky kvazikonkávní a rozpočtové omezení ji protíná ve křivce, která má jediné maximum, jak můžeme vidět na Obrázku 4.

Obr. č. 4

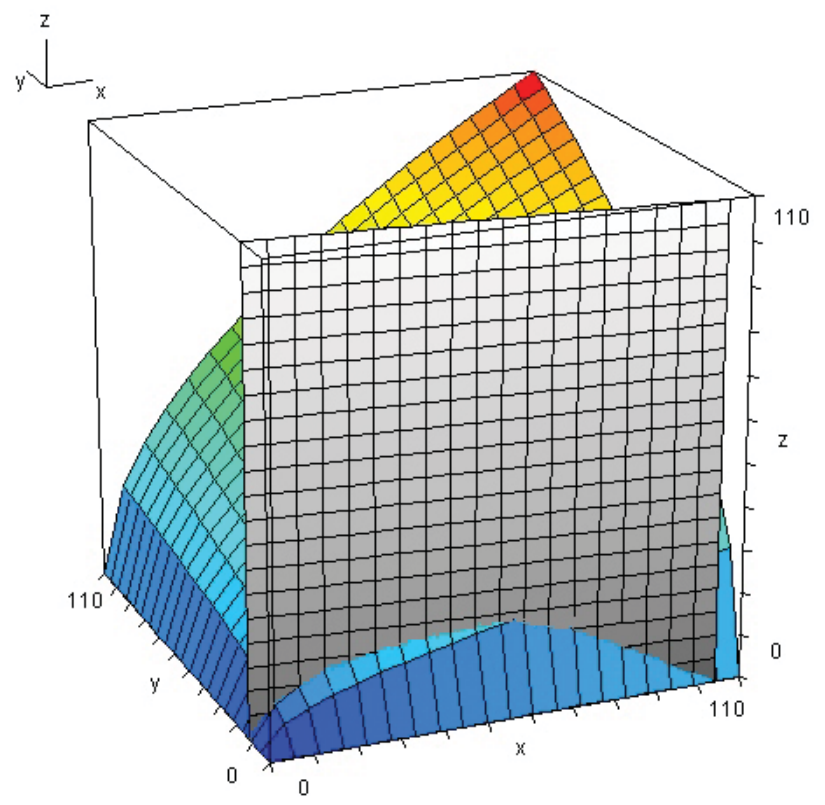

\subsubsection{Spotřebitelský koš [drůbě̆, ryby]}

Z dat uvedených v následující tabulce 4 byla odhadnuta užitková funkce ve tvaru

$$
U=x^{0,66} \cdot y^{0,34} .
$$

Příslušnou Lagrangeovu funkci můžeme tedy vyjádřit vztahem

$$
L(x, y, \lambda)=U+\lambda \cdot(1935-53 x-119 y) .
$$


Tab. č. 4: Odhad Cobb-Douglassových preferencí

\begin{tabular}{||r|r|r|r|r|r|r|r|r||}
\hline \multicolumn{1}{|c|}{ rok } & $\begin{array}{c}\text { cena } \\
\text { (drůbež) }\end{array}$ & $\begin{array}{c}\text { spotřeba } \\
\text { (drůbež) }\end{array}$ & cena (ryby) & $\begin{array}{c}\text { spotřeba } \\
\text { (ryby) }\end{array}$ & $\begin{array}{c}\text { I (drůbě̌ }+ \\
\text { ryby) }\end{array}$ & \multicolumn{1}{c|}{ S1 } & \multicolumn{1}{c|}{ S2 } & U(x,y) \\
\hline \hline 2001 & 60,55 & 22,9 & 138,06 & 5,4 & 2132,119 & 0,65033659 & 0,34966341 & 13,81790079 \\
\hline 2002 & 46,23 & 23,9 & 126,85 & 5,3 & 1777,202 & 0,621705918 & 0,378294082 & 13,51908838 \\
\hline 2003 & 53,60 & 23,8 & 114,16 & 5,3 & 1880,728 & 0,678290534 & 0,321709466 & 14,67998199 \\
\hline 2004 & 51,80 & 25,3 & 111,75 & 5,5 & 1925,165 & 0,680741651 & 0,319258349 & 15,54281042 \\
\hline 2005 & 51,60 & 26,1 & 108,53 & 5,8 & 1976,234 & 0,681478003 & 0,318521997 & 16,16508353 \\
\hline suma & $\mathbf{2 6 3 , 7 8}$ & $\mathbf{1 2 2}$ & $\mathbf{5 9 9 , 3 5}$ & $\mathbf{2 7 , 3}$ & $\mathbf{9 6 9 1 , 4 4 8}$ & $\mathbf{3 , 3 1 2 5 5 2 6 9 6}$ & $\mathbf{1 , 6 8 7 4 4 7 3 0 4}$ & $\mathbf{7 3 , 7 2 4 8 6 5 1 1}$ \\
\hline prưměr & $\mathbf{5 2 , 5 5 7 7 1 2 9 2}$ & $\mathbf{2 4 , 3 7 3 2 9 6 6 2}$ & $\mathbf{1 1 9 , 3 8 0 6 4 6 7}$ & $\mathbf{5 , 4 5 6 9 1 5 5 9 6}$ & $\mathbf{1 9 3 4 , 8 0 0 1 3 8}$ & $\mathbf{0 , 6 6 2 0 8 6 3 3 2}$ & $\mathbf{0 , 3 3 6 7 0 1 5 0 2}$ & $\mathbf{1 4 , 7 1 1 0 7 8 0 8}$ \\
\hline
\end{tabular}

Zobrazení indiferenčních křivek v letech 2001 - 2005, určení optima spotřebitele s využitím programů Derive a Maple

Odhadnutá užitková funkce byla dále použita při zobrazení indiferenčních křivek. Vztahy pro rozpočtové omezení a indiferenční křivky v jednotlivých letech byly zapsány do programu Derive.

$$
\begin{aligned}
& \text { \#1: } \quad 1935=53 \cdot x+119 \cdot y \\
& 0.65 \quad 0.35 \\
& \# 2: x \quad y=13.82 \\
& 0.62 \quad 0.38 \\
& \text { \#3: } x \cdot y=13.52 \\
& 0.68 \quad 0.32 \\
& \text { \#4: } x^{0.68} \cdot y^{0.32}=14.68 \\
& 0.68 \quad 0.32 \\
& \text { \#5: } x^{0.68} \cdot y^{0.32}=15.54 \\
& \begin{array}{ll}
0.68 & 0.32
\end{array} \\
& \text { \#6: } x \text {. } y=16.17
\end{aligned}
$$

Grafickým zobrazením těchto rovnic jsme opět získali mapu indiferenčních křivek pro jednotlivé roky a přímku znázorňující rozpočtové omezení (viz Obrázek 5). 


\section{Obr. č. 5}

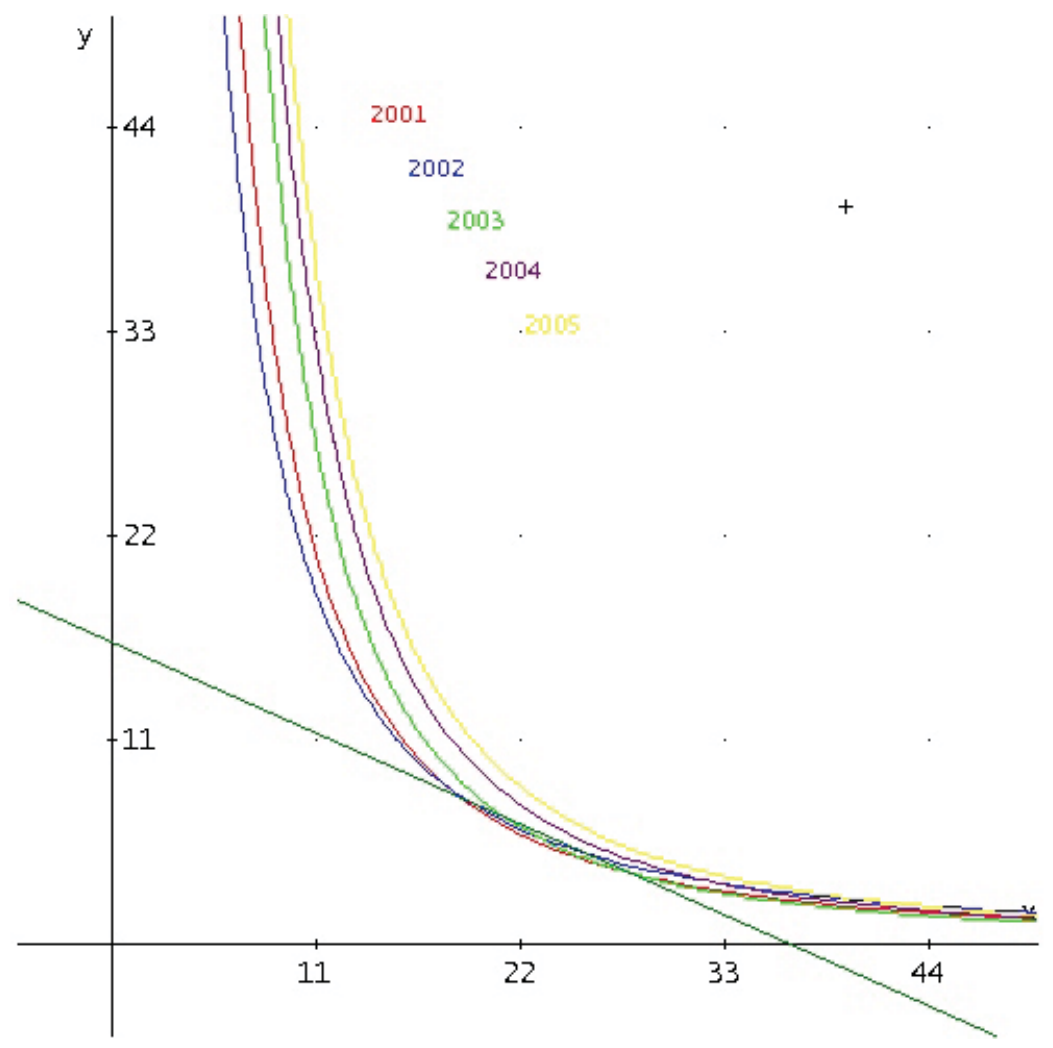

Parciální derivace Lagrangeovy funkce byly získány v programu Derive, k řešení vzniklých nelineálních rovnic byl použit program Maple.

$$
\begin{aligned}
& 0.66 \quad 0.34 \\
& \# 1: x^{0.66} \cdot y^{0.34}+\lambda \cdot(1935-53 \cdot x-119 \cdot y) \\
& \# 2: \quad \frac{d}{d x}\left(x^{0.66} \cdot y^{0.34}+\lambda \cdot(1935-53 \cdot x-119 \cdot y)\right) \\
& \text { \#3: } \quad \frac{33 \cdot y^{17 / 50}}{50 \cdot x^{17 / 50}}-53 \cdot \lambda \\
& \text { \#4: } \frac{d}{d y}\left(x^{0.66} \cdot y^{0.34}+\lambda \cdot(1935-53 \cdot x-119 \cdot y)\right) \\
& \text { \#5: } \quad \frac{17 \cdot x^{33 / 50}}{50 \cdot y^{33 / 50}}-119 \cdot \lambda \\
& \text { \#6: } \frac{d}{d \lambda}\left(x^{0.66} \cdot y^{0.34}+\lambda \cdot(1935-53 \cdot x-119 \cdot y)\right) \\
& \text { \#7: } \quad-53 \cdot x-119 \cdot y+1935
\end{aligned}
$$




$$
\begin{aligned}
& {\left[>\text { soustava }:=\left\{\left(\frac{33 \cdot y^{\frac{17}{50}}}{50 \cdot x^{\frac{17}{50}}}-53 \cdot \lambda\right)=0,\left(\frac{17 \cdot x^{\frac{33}{50}}}{50 \cdot y^{\frac{33}{50}}}-119 \cdot \lambda\right)=0,(-53 \cdot x-119 \cdot y+1935)=0\right\}\right.} \\
& \text { soustava }=\left\{-53 x-119 y+1935=0, \frac{33}{50} \frac{y^{17 / 50}}{x^{17 / 50}}-53 \lambda=0, \frac{17}{50} \frac{x^{33 / 50}}{y^{33 / 50}}-119 \lambda=0\right\} \\
& \text { solve (soustava, }\{x, y, \lambda\}) \\
& \{\lambda= \\
& \frac{1}{1078655360761389268956831716933098810331362746876078255382828500} \\
& 394223505405443668952338283139212235093387500592732330545089743531572154979471469204909 \text { १ } \\
& \left.43^{33 / 50} 10^{17 / 50} 387^{17 / 50} 70^{33 / 50}, x=\frac{12771}{530}, y=\frac{387}{70}\right\} \\
& \text { evalf }[10](\%) \\
& \{x=24.09622642, y=5.528571429, \lambda=0.007549075839\}
\end{aligned}
$$

Řešením jsme dostali následující výsledek: Při rozpočtovém omezení spotřebitele 1935 Kč je optimum spotřeby drůbeže $24,1 \mathrm{~kg}$ na osobu ročně a $5,5 \mathrm{~kg}$ ryb na osobu ročně. Z následujícího grafu odhadnuté užitkové funkce je vidět, že se jedná o typickou kvazikonkávní funkci a rozpočtové omezení je jejím řezem (viz Obrázek 6).

Obr. ̌̌. 6

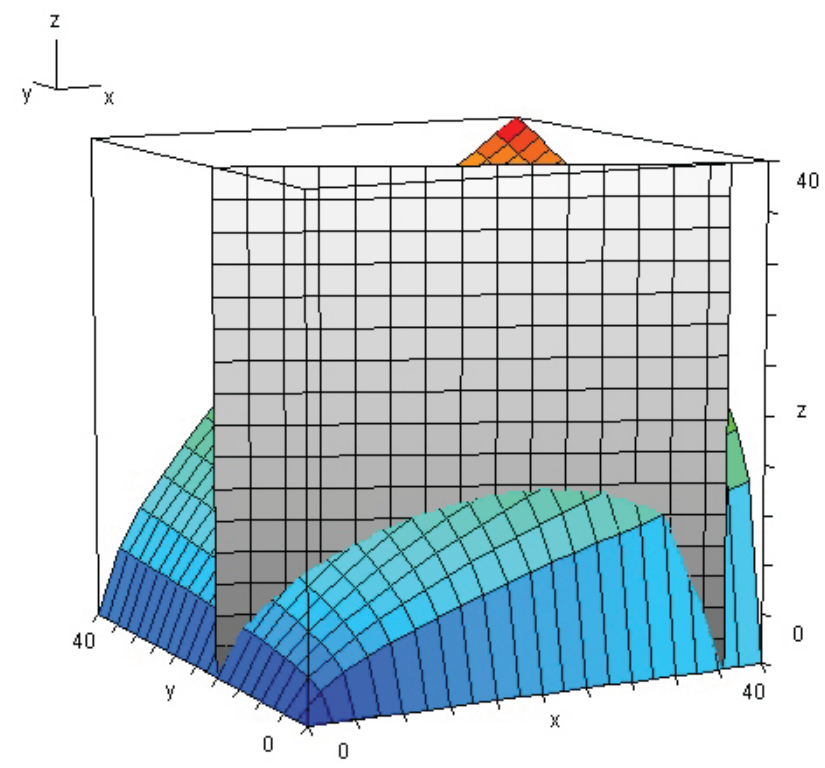

\subsubsection{Srovnání celkových užitkủ jednotlivých spotřebních košů}

Na Obrázku 7 je vidět, že z hlediska ordinálního srovnání preferencí spotřebitele přináší spotřebiteli největší užitek spotřební koš [mléko, drůbež], druhý největší užitek přináší spotřební koš [mléko, ryby] a nejmenší užitek $z$ těchto vybraných statků přináší kombinace [drůbež, ryby]. 


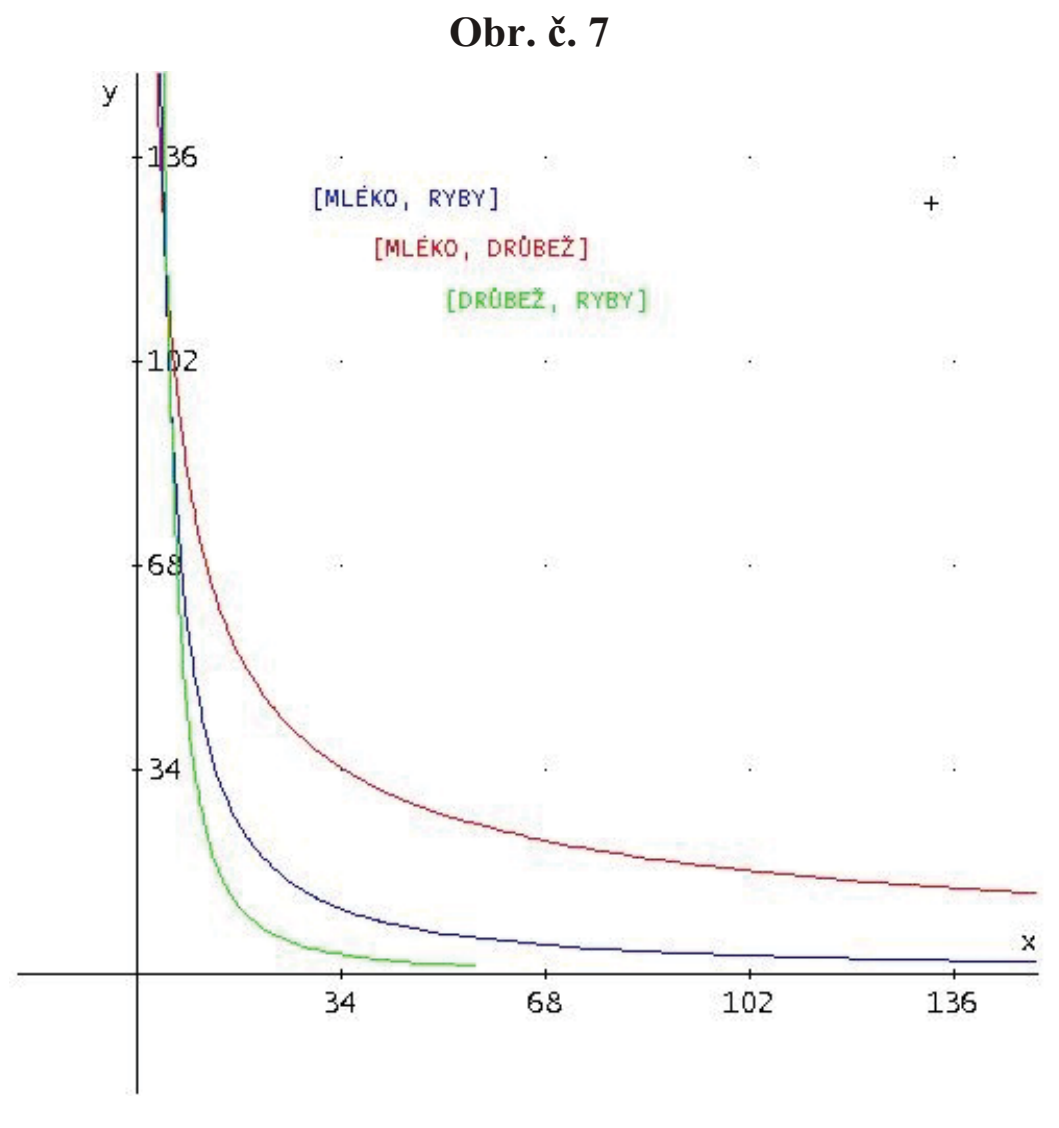

\section{Závěr}

V praktické části jsem se věnoval jednotlivým kombinacím třech vybraných spotřebních statků, kde jsem se u každého snažil zjistit, jaký je optimální poměr spotřeby dvojice statků při různých rozpočtových omezení. V teorii je řečeno, že preference mezi jednotlivými statky racionálně se rozhodující spotřebitel volí na základě disponibilního důchodu a užitku, jaký mu spotřeba statku přinese.

Z hlediska vývoje cen můžeme říci, že cena mléka velmi mírně roste, přičemž za 5 let vzrostla přibližně o 1 Kč na litr, kdežto spotřeba je v jednotlivých letech velmi nestálá, jak můžeme vidět v Tabulce 2 . Cena drůbežího masa byla v prvním roce $60 \mathrm{Kč}$, v následujícím roce rapidně klesla a v následujících se ustálila na hodnotě přibližně 52 Kč. Spotřeba drůbežího masa mírně v jednotlivých letech roste, jak můžeme vidět v Tabulce 3 . Cena ryb během jednotlivých let klesá, kdežto spotřeba je takřka konstantní, pouze v roce 2005 je mírně nad průměrem, jak můžeme vidět v Tabulce 4 .

Z hlediska ordinálního srovnání, tzn. srovnání pořadí jednotlivých spotřebních košů, můžeme říci, že průměrnému spotřebiteli přináší největší ekonomický užitek konzumace dvojice [mléko, drůbež].

\section{Literatura}

[1] BARTOŠOVÁ, Jitka. Mikro a makroekonomické úlohy řešené pomocí programu Derive5. 1. vyd. [s.1.] : Oeconomica, 2004. 85 s. ISBN 80-245-0758-7.

[2] BARTOŠOVÁ, Jitka. Modelování v ekonomii : Podpůrný učební text k on-line kurzu 6MI420. 1. vyd. [s.1.] : Oeconomica, 2007. 35 s. ISBN 978-80-245-1162-7. 
[3] Comparison of computer algebra systems [online]. 2007 , 01:56, 7 April 2007 [cit. 2007-04-10]. Dostupný z WWW: <http://en.wikipedia.org/wiki/List_of_computer_algebra_systems>.

[4] Mikroekonomie otázky [online]. 2006 [cit. 2007-04-10]. Dostupný z WWW: <http://axelx1.com/CZU/Druhy\%20rocnik/Mikroekonomie/mikro_otazky.doc>.

[5] Zdroje bílkovin. Kulturistika.com [online]. 2004 [cit. 2007-04-10]. Dostupný z WWW: <http://www.kulturistika.com/2004052302-Zdroje-bilkovin.html>.

[6] O programu Maple [online]. 2007 [cit. 2007-04-10]. Dostupný z WWW: $<$ http://www.fi.muni.cz/ hrebicek/maple/o_maplu.html $>$.

[7] Spotřebitelské ceny vybraných druhů zboži a služeb [online]. 2007 [cit. 2007-04-10]. Dostupný $\quad \mathrm{z} \quad$ WWW: $<$ http://www.czso.cz/csu/2006edicniplan.nsf/t/910022E6F2/\$File/0001060808.xls>.

[8] Spotreba potravin a nealkoholických nápojů na 1 obyvatele v $\check{C} R$ v letech $1998-2005$ [online]. 2007 [cit. 2007-04-10]. Dostupný z WWW: <http://www.czso.cz/csu/2006edicniplan.nsf/t/340038A8E8/\$File/3004rr_01.xls>.

[9] VARIAN, H.R. Mikroekonomie: moderní přistup. Libor Grega. Praha : Victoria Publishing, 1995. 643 s. ISBN 80-85865-25-4. 